\title{
Use of Latest Technologies as a Mediator between Entrepreneurial Aspiration and Open Innovation Development
}

\author{
Dusan Bobera, Bojan Lekovic
}

\author{
University of Novi Sad \\ Segedinski put 9-11 \\ 24000 Subotica, The Republic of Serbia \\ E-mail.bobera@ef.uns.ac.rs,bojan.lekovic@ef.uns.ac.rs \\ cross $^{\text {ref }}{ }^{\text {http://dx.doi.org/10.5755/j01.ee.29.2.17907 }}$
}

\begin{abstract}
Through their role, entrepreneurs differently contribute to economic activity and economic development of national economies. Some of them are driven by the development of new products/services and new markets, others try to increase their business and number of employees in line with their company's needs, while some of them see their opportunity in other markets, often beyond the borders of their country. The key issue, as well as the overall orientation of this research, is related to the analysis of the impact of entrepreneurs' aspiration (innovation, growth and internationalization) on the technological orientation, i.e. the use of new technologies in entrepreneurial venture. In order to provide deeper insight into the subject of the research, the analysis extends to cooperation with other organizations for the implementation of the open innovation strategy. The aim of this paper is to analyze the impact of entrepreneurs' aspirations on technological orientation of entrepreneurs and their cooperative capacities for the development of open innovations, and to analyze the impact of technological orientation of entrepreneurs on the implementation of the open innovation strategy. The main source of data of the analyzed factors (variables) in this study is the GEM research database for 2012. The results of path analyses of Structural Equation Modelling indicate a positive direct and indirect impact of innovation as well as entrepreneurs' aspirations and business internationalization on technological orientation of entrepreneurs and cooperation with other organizations. The positive impact was not found during the analysis of the impact of business growth and its direct impact on the technological orientation of entrepreneurs, as well as the indirect impact on cooperation with other organizations. However, when observing the growth of business enterprise and its direct impact on cooperation with other organizations, the positive impact of the observed variable is identified.
\end{abstract}

Keywords: Entrepreneurship; Growth; Innovation; Internationalization; Technology; Open Innovation.

\section{Introduction}

Having recognized the importance of entrepreneurs' aspirations to the national economy, the authors of this paper decided to review the impact of entrepreneurs' aspirations on the use of new technologies, as well as cooperation with other organizations for the development of new products/services. The key issue, as well as the overall orientation of this research, is related to the analysis of the impact of entrepreneurs' aspirations (innovation, growth and internationalization) on the technological orientation, i.e. the use of new technologies in entrepreneurial venture. In order to provide deeper insight into the subject of the research, the analysis extends to cooperation with other organizations for the development of new products/services.

The aim of this paper is to analyse the impact of entrepreneurs' aspirations (direct and indirect) on technological orientation of entrepreneurs and their cooperative capacities for the development of open innovations, and to analyse the impact of technological orientation of entrepreneurs on the implementation of the open innovation concept. The main source of data of the analysed factors (variables) in this study is the GEM research database for 2012. As our economic strategies and development policies emphasize the importance of entrepreneurship in modern economic development, it is necessary to explore entrepreneurs' aspirations both during the establishment and management of business enterprise. The mentioned entrepreneurial aspirations are positively correlated with the level of economic development through empirical research conducted by individual authors (Wennekers et al., 2010; Bosma, 2011). Identification of new technologies as a means for achieving their aims and aspirations often available only through cooperation with other institutions, shifted the focus of the authors of this paper to the research of this phenomenon.

The research is presented in four sections. In the first section of the paper, the authors presented the dominant views on entrepreneurs' aspirations (business growth, innovation and internationalization), the use of new technologies and cooperation between organizations in the development of new products/services in the form of the open innovation concept. The second section of the paper presents the methodology of the research, while the third section includes the presentation of the obtained results. On the basis of previously obtained data, the fourth section includes their qualitative analysis, comparison with other research and defined conclusions.

\section{Theoretical Background}

Entrepreneurs with their specific knowledge and skills function in different cultural and social conditions. 
Entrepreneurial perceptions regarding the society support to entrepreneurial initiative can contribute to the creation of a positive or negative decision of an individual when it comes to starting an entrepreneurial venture. For this reason, awareness of good abilities and possession of skills to start a business venture as an individual perception, and entrepreneurship as a good career choice and its positive image in the media as a social impression represents an attitudes of impact on the launch of entrepreneurial ventures. Developed positive or negative attitudes related to entrepreneurship also affect the motivation of individuals to decide to choose entrepreneurial career. The impact of entrepreneurial ventures on macroeconomic indicators is not included in the priority list of entrepreneurial goals. Entrepreneurs do not launch entrepreneurial ventures with the intention of improving the foreign trade balance, increasing gross domestic product or reducing unemployment. By their actions, consciously or not, they affect the macroeconomic indicators. Entrepreneurial motives is what really drives entrepreneur (Hessels et al., 2008). Taking into account the motive for launching an entrepreneurial venture, we distinguish two basic types of entrepreneurs, "necessity and opportunity“. Many researchers from the field of entrepreneurship have supported this concept (Acs, 2006; Gurtoo \& Williams, 2009; Hessels et al., 2008). The significance and role of this concept is recognized by „Global Entrepreneurship Monitor”. Entrepreneurial motives (opportunity and necessity) is represented in the annual reports since 2002. What makes different these two groups of entrepreneurs is the motive for launching entrepreneurial ventures. Extinguished entrepreneurs are considered as persons who have started an entrepreneurial venture out of necessity, while unlike entrepreneurs opportunists are guided by the profitable exploitation of the observed chances. Type of entrepreneurial motivation can determine aspiration for the entrepreneur. Entrepreneurs aspiring to produce novel products, to make their company grow or to indulge in export activities are bound to contribute more to economic growth than their counterparts who have lower levels of aspiration (Hessels et al, 2008). According to Global Entrepreneurship Monitor, increasing attention has been paid to particular types of entrepreneurship that have to do with aspiration levels of the individuals involved. These are entrepreneurial ventures based on the following aspirations: entrepreneurial ventures based on high growth (in terms of number of employees), innovation and internationalization.

Creation of jobs is the result of entrepreneurs' aspirations for the growth of entrepreneurial venture. Observed through the prism of GEM research, the growth of entrepreneurial venture refers to the need to increase the number of employees in entrepreneurial venture. Previous studies emphasized the impact of entrepreneurs' individual competences and personality traits by aspirations on the growth of entrepreneurial venture (Bager \& Schott, 2004; Autio, 2007; Verheul \& Mill, 2008; Terjesen \& Szerb, 2008; Karadeniz \& Ozcam, 2010). However, entrepreneurs' aspirations towards growth depends not only on the individual competences of people and characteristics of entrepreneurial venture. For this reason, Autio \& Acs
(2010) analysed the impact of intellectual property protection. Poor protection of intellectual property in a country will adversely affect the attractiveness of the invention exploitation through the establishment of new entrepreneurial ventures. This is especially the case if development of a prototype requires cooperation with complementary producers. If the level of intellectual property protection is high, inventors could develop product in cooperation with other organizations, which should result in the growth of entrepreneurial venture (Autio \& Acs 2007). Entrepreneurs who have technologies that are a potential subject of intellectual property protection may use the market for knowledge to sell, license, or franchise their intellectual property for exploitation by someone else (Autio \& Acs, 2010). Also, they can use available technology in order to produce goods or sell services. If entrepreneurs are focused on production, one of their goals is to increase the volume of production and thus exploit the benefits of the scale economy. Increasing the volume of production entails the additional engagement of the labour force, and on the basis of the aforementioned fact generates the entrepreneur's aspiration for growth in terms of employees It often happens that the engagement of new technologies or its development is beyond the resource capabilities of the enterprise. At this point, the concept of cooperation with other companies gains its significance. The development and growth of technology-based ventures are particularly dependent upon combining their own firm-specific knowledge with that of external partners because new ventures are typically resource constrained (Liao \& Welsch, 2003). This concept of is covered in studies that emphasize the impact of developed relations, in the form of created networks with other organizations in the business environment. The role of entrepreneurs is crucial in forming business relationships with other organizations, which also represents an important source of growth of entrepreneurial venture. The above-mentioned statement specifically refers to the technological entrepreneurs, where the growth of entrepreneurial venture is conditioned by cooperation with other organizations, due to resource limitations of a company (McDougall et al. 1994). Based on the previously analysed prevailing views, the authors of the paper defined the following hypotheses:

H1: Growth as entrepreneurs' aspiration has a positive effect on usage of latest technologies. At the same time, usage of latest technologies mediates the relationship between growth as an entrepreneurs' aspiration and open innovation development..

H2: Growth as an entrepreneurs' aspiration has a positive effect on open innovation development.

Innovation is usually a key factor in stimulating the development of small and medium-sized enterprises and entrepreneurs (Mahemba \& De Brujin, 2003) and their business success (Hausman, 2005). The success of innovation is based on the integration of knowledge within the innovation process. In order to succeed in their intention to develop a new product or service, entrepreneurs inevitably impose new technologies as an important part of the innovation process. The significance 
of the available technologies is conditioned by their adequate and appropriate appllication by entrepreneurs. It means, that available technologies have to be used in order to achieve defined business goals based on satisfaction of consumer needs. Technology usage by entrepreneurs should be driven by consumer needs, in order to succeed in attempt of trying to deliver real and perceived additional value of the product. Newly adopted technology can also act as an enabler of product or service innovations from the perspective of the adopter if it is successfully used to offer a new service or to deliver products to customers in a way that is new to the enterprise (Koelinger, 2008). It is well established in the broader innovation literature that technology assists in integrating internal and external inputs in innovation (Dodgson et al., 2006).

Cooperative innovation refers to active participation in joint $\mathrm{R} \& \mathrm{D}$ and other technological innovation projects with other organizations ( $\mathrm{Ru}$ et al., 2012). Generally speaking, companies that possess the necessary knowledge for development of innovations are completely independent in relation to other organizations. However, this rarely occurs. When the resource options are limited, which is the main characteristic of newly established enterprises, then the innovation potential often can be found outside the organization, in the external environment. In these situation, entrepreneurs have possibility of cooperative innovation development which allude active participation in joint $R \& D$ and other technological innovation projects with other organizations (Ru et al., 2012). Cooperation with competition not only means a reduction in costs due to joint deployment of resources, but the competition enables complementary resources and expertise for business development and generating innovation. Zhou et al. (2005) state that technological orientation of entrepreneurs, which involves the use of state-of-the-art technologies, leads to greater satisfaction of consumer's needs, and consequently to their increased satisfaction. The above statement inevitably reveals a strong technological orientation of entrepreneurs in the process of developing a new product based on different and unique ideas (Kim et al., 2013). Based on the previously analysed prevailing views, the authors of the paper defined the following hypothesis:

H3: Innovation as entrepreneurs' aspiration has a positive effect on usage of new technologies. At the same time usage of latest technologies mediates the relationship between innovation as entrepreneurs' aspiration and open innovation development.

Entrepreneurs as holders of the entrepreneurial process based on recognition and profitable exploitation of identified opportunities, often find opportunities for their venture growth beyond the borders of their country. Along with the strengthening of the world economy globalization process, an interest in the internationalization of entrepreneurial ventures is noticed in the last decade (Casas \& Dambrauskaite, 2011). Internationalization has become one of the most important factors, which determines the long-term competitiveness of the enterprise (Sekliuckiene et al., 2016). Internationalization of business is not related only to the operation of multinational companies, it is also available to newly established entrepreneurial ventures that use available technology, innovative products/services and available markets for their growth outside the framework of national economies. There are many studies that covered the internationalization of business (Blomstermo et al. 2006; Cort et al. 2007; Sakarya et al. 2007; Seggie \& Griffith, 2008), cooperation between organizations that are driven by the internationalization of business (Robson et al., 2006; Forlani et al., 2008), and technology-oriented entrepreneurs, which base their operations on the creation and use of new technology platforms (Onetti et al. 2010). Strategic decisions and directions of development of these entrepreneurial ventures are based on the interdependence of the internationalization and innovation processes. Based on the previously analysed views, the authors of the paper defined the following hypothesis:

H4: Internationalization of business as entrepreneurs' aspiration has a positive effect on the use of new technologies. At the same time, usage of latest technologies mediates the relationship between internationalization as entrepreneurs' aspiration and open innovation development.

The importance of technology-oriented entrepreneurship has grown rapidly in the last two decades. One reason is the impact of this kind of entrepreneurial venture on the economic growth of national economies (Dahlstrand, 2008). The most common concern of this type of venture is the definition of the term of technological orientation or venture based on the use of technology. Technological orientation implies constant investment in research and development activities, the use of new technologies, proactive scanning, acquisition and integration of identified technologies in company's business (Han, Kim, \& Kim, 2001). Whether it is development and usage of own technologies or in accordance to Cai et al. (2014) acquisition of external technology based on entrepreneurial orientation influences and improve new ventures' performance. These ventures are dependent on the use of technologies that do not necessarily have to be innovative and new. However, entrepreneurial ventures that involve the use of new technologies (up to one year of age according to the GEM methodology) include ventures that in their operation exploit a particular technology, developing not necessarily the same technology (Pathak et al., 2014). Whether they develop or use new technology in their entrepreneurial venture, this group of entrepreneurs contributes significantly to economic growth through business performance based on high rates of productivity (Boothby et al., 2010). Engaging technological capacities based on company's own efforts or in cooperation with other organizations, is the decision made by the organization, the operations of which are dependent on research and development activities. Firms with little or no R\&D get the knowledge inputs from other firms or public research institutions (Audretsch \& Caiazza, 2016). These organizations can receive and absorb external knowledge through technology transfer structure (technology transfer offices, science and technology parks) and formal arrangements (alliances, joint ventures, mergers and acquisitions, and corporate venture capital investments) 
Dusan Bobera, Bojan Lekovic. Use of Latest Technologies as a Mediator between Entrepreneurial Aspiration and ...

(Schildt et al., 2005). For this reason, entrepreneurial activities are focused on the acceptance of the new concept of open innovation with the aim of finding the missing resources outside the company. According to Djukic et al. (2015) open innovation is the use of purposive inflows and outflows of knowledge to accelerate internal innovation, and expand the markets for external use of innovation, respectively. These approaches assume that faster and cheaper innovation processes can be achieved by using external knowledge and stimuli, financial resources, experience, and spillover effects (Prokop \& Stejskal, 2017). The importance of this concept is highlighted by many authors in their research (Ketchen et.al., 2004; Vrande et.al., 2009; Alguzeaui \& Filieri, 2010; Enkel et al, 2010; Lee et al., 2010; Monsef et al., 2012; West \& Bogers, 2014; Saebi \& Foss, 2015). Innovation in this way can be seen as a result of joint effort by several participants. The significance of this concept grew rapidly after its successful implementation in practice. Cooperation with the competition is defined as the simultaneous cooperation (Bengtsson \& Kock, 2000) and competitive activities between companies (Gnyawali \& Byung-Jin, 2009, Bengtsson et al., 2010). Cassiman et al. (2009) recognize that profitable exploitation of innovation requires constant balancing between the cooperative and competitive forces. This concept is important for technology-oriented entrepreneurs, as it shortens the life cycle of product, research and development activities, the use of complementary technologies and the importance of technological standards (Gnyawali \& Park, 2009). Cooperation with other organizations (as direct, indirect or latent competition) definitely represents a business concept based on a compromise between cooperation and competition (Chen, 2008), but it also represents a strategy of the results of the synergistic effect (Bengtsson \& Kock, 2000). Based on the previously presented views, the authors of the paper defined the following hypothesis:
H5: Usage of new technologies has a positive effect on open innovation development.

\section{Research Methodology}

The main source of the data of analysed factors (variables) in this study is the GEM research results (Global Entrepreneurship Monitor) in 2012. GEM represents the world's leading research consortium dedicated to understanding the relationship and impact of entrepreneurship on national economic development. A research study conducted in 2012, included 69 countries and 198,000 respondents, which represents the most relevant database when it comes to the academic discipline entrepreneurship.

GEM represents one of two available international comparative data sets related to entrepreneurship (Estrin et $a l ., 2013)$. Other one is World Bank "Entrepreneurship Survey" focused on registered companies while GEM captures all entrepreneurial activity at national level (Acs et al., 2008). The authors decided to use global national level data from 2012, because GEM research methodology, from the aspect of conceptuality and comprehensiveness, leads to the results of a research that does not lose significance with the flow of time in this intensity, since it is a matter of national research. Long-term research in the field of entrepreneurship, which is enabled by this complex methodology, allows the use of a database from 2012, because it is a possible way of essential understanding of the observed phenomenon of entrepreneurial activity of a national economy. After all relevant variables were created and checked in the individual level consolidated file; national level measures were created by aggregating data on all respondents from each country. The use of the individual case weights, developed for each country, ensured that the final aggregate indicators were representative of the adult population in each country (Reynolds, 2005). Based on previous mentioned facts, GEM database is adequate for our research analysis.

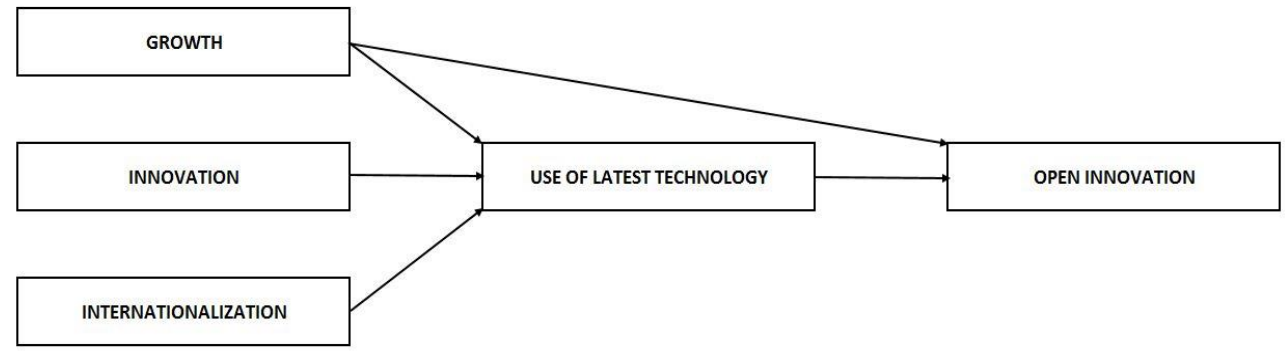

Figure 1. Conceptual Framework

Since the subject area of this paper includes entrepreneurs' aspirations and technological orientation, as well as cooperation with other organizations for development of new products/services, the authors of the paper decided to include the following variables in the study of this problem area: 1.) "\% within TEA: Product is new to all or some customers" - a variable that indicates the percentage of entrepreneurial ventures that are driven by innovations as entrepreneurial aspirations, 2.) "\%within TEA: Strong internationalization (more than $25 \%$ customers outside country" - a variable that indicates the percentage of entrepreneurial ventures that are driven by aspiration of internationalization, 3.) "\% within TEA: High job expectation $(10+$ jobs and over $50 \%$ in 5 years)" - a variable that indicates the percentage of entrepreneurial ventures that are driven by the aspiration of increase in venture in the form of the number of employees, 4.) "\% within TEA: Uses very latest technology (only available last year)" - a variable that indicates the percentage of entrepreneurial ventures which in their operations use new technology up to one year of age, 5.) "\% within TEA: Working together with other enterprises or organization to produce goods or services" - a variable that indicates the percentage of entrepreneurial ventures that collaborate with other companies or organizations in development of new products or services. Path-analysis of Structural 
Equation Modelling was used for the testing of defined research hypotheses. Figure 1 shows the conceptual framework of the research.

\section{Research Results}

Table 1 contains data indicating the statistical validity of the developed and tested model, as well as the results of the direct and indirect effects of observed variables. Having in mind the views of Kline (2010) aimed at determining the validity of the developed model, the authors observed the several parameters of the model: $\mathrm{X}^{2}(1)=0.143, \mathrm{p}=0.931 ; \mathrm{RMSEA}=0.000 ; \mathrm{CFI}=1.000$.
These results show a very suitable model as indicated by the value of RMSEA $<0.025$ (MacCallum et al., 2001). The CFI (Comparative Fit Index) value exceeds the limit value of 0.90 ( $\mathrm{Hu} \&$ Bentler, 1999). In addition, the developed model shows the value of (goodness-of-fit index) GFI $=0.999$, which is a much higher value than the limit value of 0.90 , thus indicating a very good compliance of model development with observed data. Another parameter of the model indicating its validity is (adjusted goodness-of-fit index) AGFI $=0.994$, which also exceeds the limit value of 0.90 .

Table 1

Standardized Path Coefficients

\begin{tabular}{|c|c|c|c|}
\hline Path and standardized path coefficients & Direct effect & Indirect effect & Hypotheses \\
\hline Growth $\rightarrow$ Use of latest technology & $-0.282(0.023)^{*}$ & & \\
\hline Growth $\rightarrow$ Open innovation & & $-0.128(0.026) *$ & H1: Not supported \\
\hline Growth $\rightarrow$ Open innovation & $0.278(0.013)^{*}$ & & $\mathrm{H} 2$ : Confirmed \\
\hline Innovation $\rightarrow$ Use of latest technology & $0.205(0.024) *$ & & H3. Confirmed \\
\hline Innovation $\rightarrow$ Open innovation & & $0.098(0.048)^{*}$ & H5. ConmIrmed \\
\hline Internationalization $\rightarrow$ Use of latest technology & $0.419(0.000) * *$ & & H4: Confirmed \\
\hline Internationalization $\rightarrow$ Open innovation & & $0.149(0.037)^{*}$ & \\
\hline Use of latest technology $\rightarrow$ Open innovation & $0.291(0.009)^{* *}$ & & H5: Confirmed \\
\hline Statistical parameters of model & $\begin{array}{c}\text { Threshold } \\
\text { (Hu \& Bentler,1999) }\end{array}$ & Observed & \\
\hline Chi-square/df (cmin/df) & $<3$ good & $0.143 / 2$ & \\
\hline p-value for the model & $>.05$ & 0.931 & \\
\hline CFI & $>.95$ great; $>.90$ traditional & 1.000 & \\
\hline GFI & $>.95$ & 0.999 & \\
\hline AGFI & $>.80$ & 0.994 & \\
\hline SRMR & $<.09$ & 0.0089 & \\
\hline PCLOSE & $>.05$ & 0.941 & \\
\hline RMSEA & $<.05$ good; $0.5-1.0$ moderate & 0.000 & \\
\hline $\begin{array}{l}* \mathrm{p}<0.05 \\
* * \mathrm{p}<0.01 \\
\text { Critical values (Hair et al., 1995) }\end{array}$ & & & \\
\hline
\end{tabular}

Source: Author's calculation

Starting from the hypothesis $\mathrm{H} 1$, the direct impact of the growth of venture is analysed on the use of new technologies $(\beta=-0.282, p=0.023)$, as well as the indirect impact on the growth of venture on cooperation with other organizations $(\beta=-0.128, p=0.026)$. In both the above cases, a negative impact of the observed variable is determined, which inevitably leads to the rejection of the proposed research hypothesis H1. In accordance with the proposed research hypothesis $\mathrm{H} 2$, a direct positive impact of the growth of venture is established on cooperation with other organizations

$(\beta=0.278, p=0.013)$, thereby confirming the defined hypothesis $\mathrm{H} 2$.
The positive direct impact of innovation as entrepreneurs' aspirations to the use of new technologies is also confirmed $(\beta=0.205, p=0.024)$, as well as the indirect impact on cooperation with other organizations $(\beta=0.098$, $\mathrm{p}=0.048)$, thus confirming the proposed research hypothesis $\mathrm{H} 3$. The positive direct impact of the internationalization of the business on the use of new technologies is identified $(\beta=0.419, p=0.000)$, as well as the positive indirect impact on cooperation with other organizations $(\beta=0.149, p=0.037)$, which confirmed the research hypothesis no. 4 .

The results of the analysis on how the use of new technology affects the cooperation with other organizations confirmed the research hypothesis $\mathrm{H} 5$, since a positive direct impact of the observed variable was identified $(\beta=$ $0.291, \mathrm{p}=0.009$ ). 


\section{Discussion and Conclusion}

Assuming the use of new technologies by entrepreneurs who expressed aspiration to the growth of a business venture, as an increase in the number of employees, and analysing the obtained results, the authors of this paper revealed a negative impact of the observed variable. In this case, the hypothesis $\mathrm{H} 1$ is rejected and the impact of the growth of business venture on the use of new technology represents an area where different results occur. A literature review indicated the possibility of similar results. Analysing the entrepreneurs of the Republic of Slovenia, based on the GEM research, Sirec et al. (2010) found the positive impact of the growth aspiration of entrepreneurial ventures when it comes to growth observed through the increase of sales or fixed assets of a company. A statistically significant effect was absent only in the case of observing the growth of business enterprise through the prism of the number of employees. A possible reason for getting different results in researching the effects of growth on the use of new technologies or other observed variables, lies in the fact that nascent entrepreneurs and owners of existing ventures were surveyed. It is believed that nascent entrepreneurs are more ambitious in the estimates for the required number of employees in the following business period. This could be the reason for their bias and miscalculations. Furthermore, owners of new and existing ventures, entrepreneurs with extensive experience are moderate in their assessments, which leads to different results in analysing the impact of the observed variable.

Anticipating the possibility of obtaining different results, based on the above facts, the authors of this paper decided to observe a direct impact of the growth on cooperation with other organizations. In this case, a positive effect is identified, thus confirming the hypothesis $\mathrm{H} 2$. The results are in line with the research conducted by Liao \& Welsch (2003) that defined the impact of increased growth aspiration on cooperation with other organizations for technology-oriented entrepreneurs, through the creation of strong social ties. The same effect was also observed for (non)technology-oriented entrepreneurs.

The research results confirmed the hypothesis $\mathrm{H} 3$, which confirmed both direct impact of innovations as aspirations to the use of new technologies and indirect impact on cooperation with other organizations. The results are in full accordance with the results of the studies that found a positive impact of the use of new technologies in development of new products. Kim et al. (2013) also found that entrepreneurs' technological orientation increases the chances of development of new products, having recognized that entrepreneurs more frequently used new technologies in the development of new products. The possibility of development and use of new technologies to a large extent determines the level of product innovation. Entrepreneurs who possess knowledge and skills for the use of new technologies also show a greater degree of innovation, i.e. innovative performance of developed products. Yu et al. (2014) found a positive impact of the possibility of development and use of new technologies in development of new products.
The direct impact of the internationalization of business on the use of new technologies as well as its indirect impact on cooperation with other organizations in development of new products/services, is confirmed by the obtained results of the statistical analysis, thereby confirming the hypothesis H4. The results are in favour of the assumption of the use of new technologies in the internationalization of business and are in accordance with the results of research conducted by Hessels \& Terjesen (2008). The results represent the extension of available research conducted. Brach \& Naude (2012) confirmed the results in the context of their research including the highlydeveloped countries. A step forward in observing technologies, i.e. their classification, was made in the research conducted by Amoros et al. (2016). In their study, they analysed the impact of the used technology from one to five years of age. The results of the study, which observed the impact of new technologies up to one year of age, are in full compliance with the above-mentioned research, thus confirming the importance of classification of technologies based on how new they are. Recent analyses have shown that the SMEs' exports capabilities are highly dependent on co-opetition, while others suggest that the challenges of international supply chain constitute a major driver to this combination (Galdeano-Gomez et al., 2016).

The observed positive direct impact of the use of new technologies on cooperation with other organizations contributed to the confirmation of the hypothesis H5. Cooperation with other organizations offers the possibility of acquiring new technological knowledge for the development of new products or services (Ritala et al., 2009). Therefore, based on the development of cooperative forces and company's capabilities, cooperation with other organizations is the possibility for development of a business venture by technology-oriented entrepreneurs. Research results are in line with the research conducted by Brettel \& Cleven (2011), who found a positive impact of technology-oriented entrepreneurs on cooperation with organizations, emphasizing universities and suppliers as institutions whose statistical significance was revealed in the analysis of their relations. Positive insignificant impact was observed in the competition, which is understandable, recognizing the complexity of relations between competitors that acquire and develop their competitive advantage based on new technologies. Therefore, cooperation between technology-oriented entrepreneurs occurs in rare and exceptional cases (Miotti \& Sachwald, 2003). The contribution of this paper is reflected in the comprehensive observation of entrepreneurs' aspirations and the emphasis on technology as a means for achieving high growth of a venture, development of new products/services and early internationalization of products. Based on the realized entrepreneurs' aspirations, a significant impact of launched entrepreneurial ventures can be expected on the performance of the national economy. The results show to decision-makers the unambiguous importance of the use of new technologies for the realization of entrepreneurs' aspirations. Therefore, when creating the future development policies, decisionmakers have to emphasize not only the use but also the development of new technologies. While the technology is 
identified as one of the factors that facilitate knowledge flow and an interdependent innovation process, its contribution is not widely explored in the open innovation literature (Dodgson et al., 2006). Contribution of the paper can be also recognized in significant accentuation and promotion of open innovation concept, having in mind the resource limitations of current economic participants on the market. The need for this concept is more pronounced than it has ever been. In particular, the development and use of new technologies and the concept of open innovation, refers to the concept of technology transfer, connecting university centres, research and development and scientific-research institutions with business entities.
Promoting the concept of open innovation through the emphasis of human and entrepreneurial capital, cooperative and competitive unrevealed potential, represents neglected resources in improving the innovative capacities of the national economy. One of the limitations of this study, which also represents an opportunity for future research, is the lack of entrepreneurial venture classification. The inclusion of moderator variables would enable the analysis of the results in the manufacturing or service sector, with the aim of identifying the nature of a venture and the impact of new technologies on the business results within specific industrial sectors.

\section{References}

Acs, Z. J. (2006). How is entrepreneurship good for economic growth? Innovations, 1(1), 97-107. https://doi.org/10.1162/itgg.2006.1.1.97

Acs, Z. J., Desai, S., \& Klapper, L. F. (2008). What does "entrepreneurship" data really show? Small Business Economics, 31, 265-281. https://doi.org/10.1007/s11187-008-9137-7

Alguezaui, S., \& Filieri, R. (2010). Investigating the role of social capital in innovation: sparse versus dense network. Journal of knowledge management, 14(6), 891-909. https://doi.org/10.1108/13673271011084925

Amoros, J. E., Basco, R., \& Romaní, G. (2016). Determinants of early internationalization of new firms: The case of Chile. International Entrepreneurship and Management Journal, 12(1), 283-307. https://doi.org/10.1007/s11365014-0343-2

Audretsch, D., \& Caiazza, R. (2016). Technology transfer and entrepreneurship: cross-national analysis. The Journal of Technology Transfer, 41(6), 1247-1259. https://doi.org/10.1007/s10961-015-9441-8

Autio, E. (2007). Global Report on High-Growth Entrepreneurship. London Business School/Mazars/Babson.

Autio, E., \& Acs, Z., (2007), Individual and country level determinants of growth aspiration in new ventures, Babson Conference on Entrepreneurship Research, Madrid, 6-9 June 2007.

Autio, E., \& Acs, Z. (2010). Intelectual property protection and the formation of entrepreneurial growth aspirations. Strategic Entrepreneurship Journal, 4, 234-251. https://doi.org/10.1002/sej.93

Bager, T., \& Schott, T. (2004). Growth Expectations by Entrepreneurs in Nascent Firms, Baby Businesses and Mature Firms: Analysis of the Global Entrepreneurship Monitor

Bengtsson, M., \& Kock, S. (2000). "Coopetition" in business networks - to cooperate and compete simultaneously. Industrial Marketing Management, 29 (5), 411-426. https://doi.org/10.1016/S0019-8501(99)00067-X

Bengtsson, M., Eriksson, J., \&Wincent, J. (2010). Coopetition: new ideas for a new paradigm. In: Yami, S., Castaldo, S., Dagnino, G. B., Le Roy, F. (Eds.), Coopetition: Winning Strategies for the 21st Century. Edward Elgar, Northampton, MA, 19-39. https://doi.org/10.4337/9781849807241.00009

Blomstermo, A., Sharma, D. D., \& Sallis, J. (2006), Choice of foreign entry mode in service firms. International Marketing Review, 23(2), 211-229. https://doi.org/10.1108/02651330610660092

Boothby, D., Dufour, A., \& Tang, J. (2010). Technology adoption, training and productivity performance. Research Policy, 39(5), 650-661. https://doi.org/10.1016/j.respol.2010.02.011

Bosma, N. S. (2011). Entrepreneurship, Urbanization Economies and Productivity of European Regions, in M.F. Fritsch (ed.). Handbook of Research on Entrepreneurship and Regional Development, (pp.,107-132), Cheltenham (UK); Northampton, MA (USA): Edward Elgar. https://doi.org/10.4337/9780857936493.00009

Brach, J., \& Naude, W. (2012). International entrepreneurship and technological capabilities in the Middle East and North Africa. UNU-MERIT working papers. Netherlands: United Nations University.

Brettel, M., \& Cleven, N. J. (2011). Innovation culture, collaboration with external partners and NPD performance. Creativity and Innovation Management, 20(4), 253-272. https://doi.org/10.1111/j.1467-8691.2011.00617.x

Cai, L., Liu, Q., Deng, S., \& Cao, D. (2014). Entrepreneurial orientation and external technology acquisition: an empirical test on performance of technology-based new ventures. Journal of Business Economics and Management, 15(3), 544-561. https://doi.org/10.3846/16111699.2013.770786

Casas, R., \& Dambrauskaite, V. (2011). Factors of the innovation-friendly external business environment in Lithuania, promoting the emergence of the 'born global' companies, Business: Theory and Practice 12(4), 31-39.

Cassiman, B., Di Guardo, M. C., \& Valentini, G. (2009). Organising R\&D projects to profit from innovation: Insights from coopetition. Long Range Planning, 42(2), 216-233. https://doi.org/10.1016/j.lrp.2009.01.001 
Dusan Bobera, Bojan Lekovic. Use of Latest Technologies as a Mediator between Entrepreneurial Aspiration and ...

Chen, M. J. (2008). Reconceptualizing the competition-cooperation relationship: a transparadox perspective. Journal of Management Inquiry 17(4), 288-305. https://doi.org/10.1177/1056492607312577

Cort, K.T., Griffith, D. A., \& White, D. S. (2007). "An attribution theory approach for understanding the internationalization of professional service firms". International Marketing Review, 24(1), 9-25. https://doi.org/ $10.1108 / 02651330710727169$

Dahlstrand, A., (2007). Technology-based entrepreneurship and regional development: the case of Sweden. European Business Review, 19(5), 373-386. https://doi.org/10.1108/09555340710818969

Djukic, S., Stankovic, L., \& Lepojevic, V. (2015). Improvement of Innovation Capacity of SMEs in Republic of Serbia by Connecting with Key Stakeholders. Inzinerine Ekonomika-Engineering Economics, 26(4), 431-441. https://doi.org/ 10.5755/j01.ee.26.4.8489

Dodgson, M., Gann, D., \& Salter, A. (2006). The role of technology in the shift towards open innovation: the case of Procter \& Gamble. R\&D Management, 36(3), 333-346. https://doi.org/10.1111/j.1467-9310.2006.00429.x

Enkel, E., Gassmann, O., \& Chesbrough, H. (2009). Open R\&D and open innovation: exploring the phenomenon. R\&D Management, 39(4), 311-316. https://doi.org/10.1111/j.1467-9310.2009.00570.x

Forlani, D. M., Parthasaranthy, M., \& Keaveney, S.M. (2008), Managerial risk perceptions of international entry mode strategies: the interaction effect of control and capability. International Marketing Review, 25(3), $292-311$. https://doi.org/10.1108/02651330810877225

Galdeano-Gomez, E., Perez-Mesa, J. C., \& Aznar-Sanchez, J. A. (2016). Internationalisation of SMEs and simultaneous strategies of cooperation and competition: an exploratory analysis. Journal of Business Economics and Management, 17(6), 1114-1132. https://doi.org/10.3846/16111699.2014.959040

Gnyawali, D. R., \& Park, B. J. R. (2009). Co-opetition and Technological Innovation in Small and Medium-Sized Enterprises: A Multilevel Conceptual Model. Journal of Small Business Management, 47(3), 308-330. https://doi.org/ 10.1111/j.1540-627X.2009.00273.x

Gurtoo, A., \& Williams, C. C. (2009). Entrepreneurship and the informal sector: Some lessons from India, Entrepreneurship and Innovation, 10(1), 1-8. https://doi.org/10.5367/000000009787414280

Estrin, S., Mickiewicz, T., \& Stephan, U. (2013). Entrepreneurship, social capital, and institutions: Social and commercial entrepreneurship across nations. Entrepreneurship Theory and Practice, 37 (3), 479-504. https://doi.org/ 10.1111/etap.12019

Hair, J., Anderson, R., Tatham, R., \& Black, W. (1995). Multivariate data analysis. Upper Saddle River, NJ: Prentice Hall, $168-182$.

Hausman, A. (2005). Innovativeness among small businesses: Theory and propositions for future research. Industrial Marketing Management, 34(8), 773-782. https://doi.org/10.1016/j.indmarman.2004.12.009

Han, J. K., Kim, N., \& Kim, H. (2001). Entry barriers: A dull-, one-, or two-edged sword for incumbents? Unraveling the paradox from a contingency perspective. Journal of Marketing, 65 (January). 1-14. https://doi.org/ 10.1509/jmkg.65.1.1.18133

Hu, L., \& Bentler, P. M. (1999). Cutoff Criteria for Fit Indexes in Covariance Structure Analysis: Conventional Criteria versus New Alternatives. Structural Equation Modeling: A Multidisciplinary Journal, 6(1), 1-55. https://doi.org/10.1080/10705519909540118

Hessels, J., \& Terjesen, S. (2008). Entrepreneurial career capital, and new venture export orientation. In J.Hessels (Ed.), International entrepreneurship value creation across borders. Rotterdam: Erasmus Research Institute of Management.

Hessels, J., Gelderen, M., \& Thurik, R., (2008). Entrepreneurial aspirations motivations, and their drivers. Small Business Economics, 31, pp. 323-339. https://doi.org/10.1007/s11187-008-9134-X

Karadeniz, E., \& Ozcam, A., (2010). The determinants of the growth expectations of the early stage entrepreneurs (TEA) using the ordinal logistic model (OLM): The case of Turkey. Economic and Business Review, 12(1), 61-84.

Karin, S., Tominc, P., \& Rebernik, M. (2010). Gender differences in the growth aspirations and technology orientation of Slovenian entrepreneurs. Women entrepreneurs and the global environment for growth, 323-344.

Ketchen, D. J., Snow, C. C., \& Hoover, V. L. (2004). Research on competitive dynamics: Recent accomplishments and future challenges. Journal of Management, 30(6), 779-804. https://doi.org/10.1016/j.jm.2004.06.002

Kim, N., Im, S., \& Slater, S. F. (2013). Impact of knowledge type and strategic orientation on new product creativity and advantage in high-technology firms. Journal of Product Innovation Management, 30(1), $136-153$. https://doi.org/10.1111/j.1540-5885.2012.00992.x

Koellinger, P. (2008). The relationship between technology, innovation, and firm performance-Empirical evidence from e-business in Europe. Research policy, 37(8), 1317-1328. https://doi.org/10.1016/j.respol.2008.04.024

Lee, S., Park, G., Yoon, B., \& Park, J. (2010). Open innovation in SMEs - An intermediated network model. Research Policy, 39(2), 290-300. https://doi.org/10.1016/j.respol.2009.12.009 
Liao, J., \& Welsch, H. (2003). Social capital and entrepreneurial growth aspiration: a comparison of technology-and nontechnology-based nascent entrepreneurs. The Journal of high technology management research, 14(1), 149-170. https://doi.org/10.1016/S1047-8310(03)00009-9

MacCallum, R. C., Widaman, K. F., Preacher, K., \& Hong, S. (2001). Sample Size in Factor Analysis: The Role of Model Error. Multivariate Behavioral Research, 36(4), 611-637. https://doi.org/10.1207/S15327906MBR3604_06

Mahemba, C. M., \& De Bruijn, E. J. (2003). Innovation activities by small and medium-sized manufacturing enterprises in Tanzania. Creativity and Innovation Management, 12(3),162-173. https://doi.org/10.1111/1467-8691.00279

McDougall, P. P., Shane, S., \& Oviat, B. M. (1994). Explaining the formation of international new ventures: the limits of theories from international business research. Journal of Business Venturing, 9, $469-487$. https://doi.org/10.1016/0883-9026(94)90017-5

Miotti, L., \& Sachwald, F. (2003). Co-operative R\&D: Why and with Whom? An Integrated Framework of Analysis. Research Policy, 32, 1481-1499. https://doi.org/10.1016/S0048-7333(02)00159-2

Monsef, S., Khairuzaman, W., \& Ismail, W. (2012). The Impact of Open Innovation in New Product Development Process. International Journal of Fundamental Psychology \& Social Sciences, 2(1), 7-12.

Onetti, A., Zucchella, A., Jones, M. V., \& McDougall-Covin, P. P. (2012). Internationalization, innovation and entrepreneurship: business models for new technology-based firms. Journal of Management \& Governance, 16(3), 337-368. https://doi.org/10.1007/s10997-010-9154-1

Pathak, S., Muralidharan, E., \& Laplume, A. (2014). Home country factors and the decision to internationalize technologybased new ventures: A multi-level study of early-stage entrepreneurs. Frontiers of Entrepreneurship Research, 34(19), 1.

Prokop, V., \& Stejskal, J. (2017). Different Approaches to Managing Innovation Activities: An Analysis of Strong, Moderate, and Modest Innovators. Inzinerine Ekonomika-Engineering Economics, 28(1), 47-55. http://dx.doi.org/10.5755/j01.ee.28.1.16111

Reynolds, P., Bosma, N., Autio, E., Hunt, S., De Bono, N., Servais, I., \& Chin, N. (2005). Global entrepreneurship monitor: Data collection design and implementation 1998-2003. Small business economics, 24(3), $205-231$. https://doi.org/10.1007/s11187-005-1980-1

Ritala, P., Hurmelinna-Laukkanen, P., \& Blomqvist, K., (2009). Tug of war in innov-ation- coopetitive service development. International Journal of Services Technology and Management, 12(3), $255-272$. https://doi.org/10.1504/IJSTM.2009.025390

Ru, P., Zhi, Q., Zhang, F., Zhong, X., Li, J., \& Su, J. (2012). Behind the development of technology: The transition of innovation modes in China's wind turbine manufacturing industry. Energy Policy, 43, 58-69. https://doi.org/10.10 16/j.enpol.2011.12.025

Robson, M. J., Skarmeas, D., \& Spyropoulou, S. (2006). Behavioral attributes and performance in international strategic alliances: review and future directions. International Marketing Review, 23(6), 585-609. https://doi.org/10.1108/02651330610712120

Saebi, T., \& Foss, N. J. (2015). Business models for open innovation: Matching heterogeneous open innovation strategies with business model dimensions. European Management Journal, 33(3), 201-213. https://doi.org/10.10 16/j.emj.2014.11.002

Sakarya, S., Eckman, M., \& Hyllegard, K.H. (2007). Market selection for international expansion: assessing opportunities in emerging markets. International Marketing Review, 24(2), 208-238. https://doi.org/10.1108/02651330710741820

Seggie, S. H., \& Griffith, D. A. (2008). The resource matching foundations of competitive advantage: an alternative perspective of the globalization of service firms. International Marketing Review, 25(3), $262-275$. https://doi.org/10.1108/02651330810877207

Sekliuckiene, J., Sedziniauskiene, R., \& Viburys, V. (2016). Adoption of Open Innovation in the Internationalization of Knowledge Intensive Firms. Inzinerine Ekonomika-Engineering Economics, 27(5), $607-617$. https://doi.org/10.5755/j01.ee.27.5.15371

Schildt, H. A., Maula, M. V., \& Keil, T. (2005). Explorative and exploitative learning from external corporate ventures. Entrepreneurship Theory and Practice, 29(4), 493-515. https://doi.org/10.1111/j.1540-6520.2005.00095.x

Sirec, K., Tominc, P., \& Rebernik, M. (2010). Gender differences in the growth aspirations and technology orientation of Slovenian entrepreneurs. Women entrepreneurs and the global environment for growth, 323-344.

Terjesen, S., \& Szerb, L. (2008). Dice Thrown from the Begining? An Empirical Investigation of Determinants of Firm Level Growth Expectations. Estudio de Economia, 35(2), 153-178.

Verheul, I., \& Van Mil, L. (2008). What Determines the Growth Ambition of Dutch Early-stage Entrepreneurs? Scientific Analysis of Entrepreneurship and SMEs, H200811.

Vrande, V., Jong, J., Vanhaverbeke, W., \& Rochemont, M., (2009). Open Inovation in SME's: Trends. Motives and Management Chalanges, Technovation, 29, 423-437. https://doi.org/10.1016/j.technovation.2008.10.001 
Dusan Bobera, Bojan Lekovic. Use of Latest Technologies as a Mediator between Entrepreneurial Aspiration and ...

Walley, K., (2007). Coopetition: an introduction to the subject and an agenda for research. International Studies of Management \& Organization, 37 (2),11-31. https://doi.org/10.2753/IMO0020-8825370201

Wennekers, S., Van Stel, A., Carree, M., \& Thurik, A. R. (2010). The relationship between entrepreneurship and economic development: Is it U-shaped?. Foundations and Trends in Entrepreneurship, 6(3), $167-237$. https://doi.org/10.1561/0300000023

West, J., \& Bogers, M. (2014). Leveraging external sources of innovation: a review of research on open innovation. Journal of Product Innovation Management, 31(4), 814-831. https://doi.org/10.1111/jpim.12125

Yu, B., Hao, S., Ahlstrom, D., Si, S., \& Liang, D. (2014). Entrepreneurial firms' network competence, technological capability, and new product development performance. Asia Pacific Journal of Management, 31(3), 687-704. https://doi.org/10.1007/s10490-013-9365-5

Zhou, K. Z., Yim, K., \& Tse. K., (2005). The effects of strategic orientations on technology- and market-based breakthrough innovations. Journal of Marketing, 69 (April), 42-60. https://doi.org/10.1509/jmkg.69.2.42.60756

The article has been reviewed.

Received in April 2017; accepted in April, 2018. 